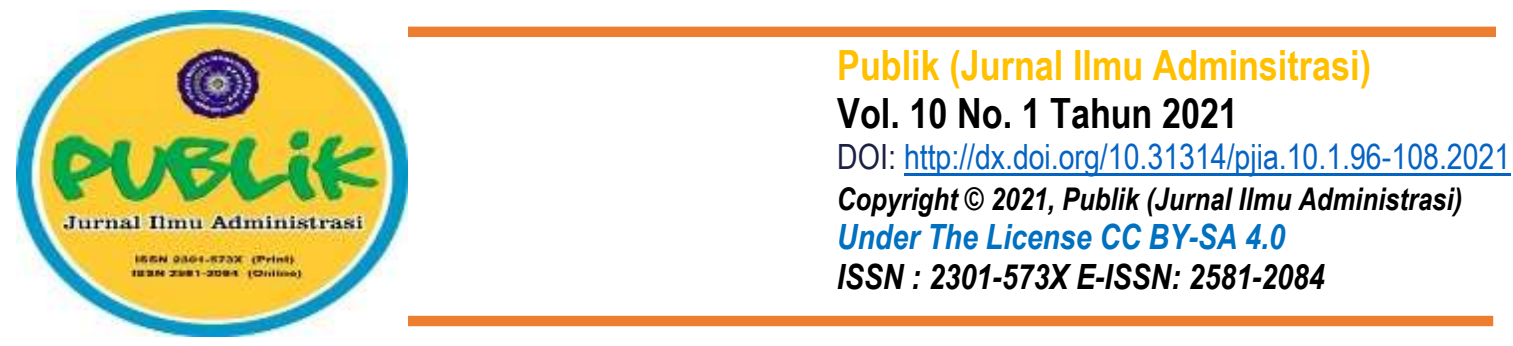

\title{
Effectiveness of Waste Management in Bitung City Environmental
} Agency

\author{
Audy G.H. Lengkong ${ }^{1}$, Lexi Lumingkewas², Fitri H. Mamonto³ \\ ${ }^{12} 23$ Universitas Negeri Manado \\ Email: audylengkong@gmail.com, lexilumingkewas@unima.ac.id, fitrimamonto@unima.ac.id
}

\begin{abstract}
This study aims to analyze and describe the effectiveness of Waste Management at the Bitung City Environmental Service. The concept used is about the management of public services, the effectiveness of public services and excellent public services. The method used is qualitative, with a focus on the effectiveness of waste management through indicators of sorting, collecting, transporting and processing waste. Sources of data are leaders, structural officials in the field of waste management, supervisors and field officers and the community. The results showed that the waste had not been sorted and separated according to the type, time and place of disposing of the waste had not been complied with according to regulations, as well as the limited number and ability of collecting officers. Limited number and capacity of transportation means, working time or transportation cycle, not all waste has been processed and utilized through waste processing facilities. This study concludes: 1.) The collected waste has not been sorted and separated 2.) The collection of waste by field officers in all areas has not been maximized. 3.) Limited number of fleets, means of transportation, and working time and transportation cycles. 4.) Waste processing and utilization has not been maximized. There are several factors that affect the effectiveness of waste management at the Bitung City Environmental Service, including; Human resources, facilities and infrastructure, rules and regulations, limited land area for landfill.
\end{abstract}

Keywords: Effectiveness; Waste Management; Public Service

Received: 09-05-2021 Revised:09-06-2021 Accepted:14-06-2021

\section{INTRODUCTION}

In the era of regional autonomy with the granting of authority to regulate and manage their own household affairs, it has given logical consequences to the local government has authority through regional devices in conducting government affairs. The purpose of granting authority to the region is to bring closer services to the community in the hope of becoming more sensitive and responsive to the needs of public services. Every government institution is expected to provide more public services directed at the more effective and efficient quality of services. Competence and professionalism in the service become the main solution that must be owned by every local 
government organization in providing public services. The quality of work is the answer to all service needs and the handling of public problems.

One of the environmental problems that is always a concern and generally present in every urban area is the problem of garbage. Along with the rapid population growth, especially in urban areas that increase in population, has triggered increasing activity and needs of the community, both primary, secondary and other complementary needs, even consumption and use of consumables / packaging products are increasing and will potentially become a source of waste.

Waste that is part of the rest of human activities needs to be managed so as not to cause various problems to human life or impact on the surrounding environment such as environmental pollution and the spread of disease, as well as affect the aesthetics of the local environment. Waste management should be carried out as part of public services by paying attention to environmental aspects and carried out on an ongoing basis.

In Law No. 18 of 2008 mandates that waste management must be carried out systematically, thoroughly, and sustainably which includes the reduction and handling of waste. The way out of waste management is done integratively organized from upstream to downstream, including to the impacts that may arise in it. One of the pillars in the implementation of good governance is the commitment to environmental issues, which means that waste management is needed based on the principle of sustainability for environmental sustainability. The success of regional development is not only measured by economic growth and welfare but by the feasibility and comfort of public services provided including handling in waste management in Bitung City.

Waste management by the Environment Office of Bitung City as a technical institution aims to realize the improvement of knowledge, awareness and participation of the community and all stakeholders in sustainable environmental development with the aim of improving waste management through the expansion program cthe management of waste services with the support of waste managementfacilities and socialization of waste management so that it can be managed by involving all parties. This waste management effort is supported by infrastructure facilities, among others, 21 garbage trucks, 10 garbage motors, 54 containers, 125 permanent TPS, 150 trash cans, 4 TPS3R, 17 compost sites, and 1 landfill. (DLH Bitung City 2020)

The condition of Bitung City which has an area of $313.50 \mathrm{~km} 2$ with a population of 223,926 people, has the potential to produce a volume of garbage arising of 111.9 tons / day, while the volume of garbage carried 97.35 tons / hr and uncontested by 14.55 tons / hr. This demands efforts made to handle waste in urban areas with human resources and facilities owned, but there is still a buildup of waste in tps and in various open places, as well as reduced capacity of waste 
processing facilities, along with the increasing population growth and expansion of residential areas. With the increasing number of people who have the potential to increase the volume of waste production, it requires the support of all parties, especially local governments with service management, innovating and utilizing existing resources, conducting waste management to improve public health and environmental quality and making waste as a resource that can be utilized. According to Hadiwiyoto (1983) That in waste management is attempted to minimize or possibly eliminate problems that arise related to the environment and need to pay attention to the process ranging from collection, separation, burning and decomposition (hoarding) waste. Thus, in waste management is directed to reduce the impact on the environment through efforts in accordance with the stages and processes technically operational starting from the time of sorting, collection, utilization, and disposal / final disposal. In Law No. 18/2008 mandates that waste management activities, be carried out on a systematic, thorough, and sustainable basis to improve public health and environmental quality and make waste as a resource.

There are some previous studies relate to the waste management: Juvinus Kobogau et al., (2018) In a study that focused on the performance of the Mimika District Cleaning Service in waste management concluded that the performance of the cleaning service needs to be improved starting from the process of sorting, collecting, and transportation. Maximizing cooperation with relevant agencies and private parties, through socialization about waste utilization. Agnesia Natania Lumiu (2017) in a study on the efficiency of cleaning services Company Cleaning area of Bandung in the village of Pasir Kaliki, with the focus of what factors are the cause of not optimal cleaning. That regulatory factor is a factor that affects the effectiveness of cleaning services provided because BUMD cannot carry out the function of formulating the technical policy of management because the policy formulated is limited to financial aspects. In this research has not been maximized waste management because the management process is systematics, thorough and sustainable has not been done starting from the process of sorting, collection, transportation, and processing of waste due to limitations in the capabilities of existing. Resources, both human and facilities and infrastructure, the application of regulations and regulations and the involvement of stakeholders in waste management. Based on the background of the problem, research and assessment was conducted with the aim of analyzing the effectiveness of waste management at the Bitung City Environment Office. 


\section{METHODS}

This research was conducted using qualitative research design from Miles and Huberman in Sugiyono (2018). The design was appropriate with the purposes of this research which is focused on the Effectiveness of Waste Management in Bitung City Environmental Office, through indicators: Sorting Collection, Transportation, and Waste Processing. Interview data obtained from leaders, structural officials in the field of waste management, supervisors, and field officers as well as the public. Documentation, conducted through the organizational structure and management of waste management services at the Bitung City Environment Office and observation by observing waste management activities. All three data are analyzed descriptively. There are numbers of informants as a subject of this research they are: Bitung City Environmental Cadre, Secretary of The Office, Head of Waste Management, Head of Waste Handling section, Head of Landfill, Supervisors and Field Officers, Society.

\section{RESULTS AND DISCUSSION}

The effectiveness of a public organization in providing services depends on the extent of the ability of the organization in applying the principles of service management by utilizing all the potentials and resources owned. The purpose of organizations or public institutions in service is to provide products and ease of service both goods and services that can be enjoyed and provide satisfaction to the public. The concept of public service according to Kurniawan in Sinambela (2006) mentions public service is interpreted, the provision of services (serving) the needs of people or communities who have interests in the organization in accordance with the main rules and ordinances that have been established. The services provided are closely related to the fulfillment of public needs by the service provider. In line with this, according to Law No. 25 of 2009, that public service is an activity or a series of activities in order to fulfill the needs of services in accordance with the laws and regulations for every citizen and resident on goods, services, and / or administrative services provided by public service providers.. Public services are present in resolving public issues faced by service recipients or the public in general and carried out by service providers who are responsible for the service. Waste services by local governments conducted by service providers as a form of public services to solve the problem of waste that can affect people and the environment. According to Kodoatie (2003), Waste is a solid, semi-solid waste that is a byproduct of urban activities or life cycles of humans, animals or plants. Garbage is also defined as the rest of human daily activities and/or natural processes in the form of solids (Law No. 18/ 2008). Thus it can be said that garbage as a solid-shaped object and is the rest of human activities and / or natural processes must be managed so as not to impact the environment. To avoid the 
impact for people and the environment, waste management becomes a necessity to be managed in terms of service management.

There is no denying that the waste management process will run effectively if the management of the service is directed at achieving the expected goals with little improvement of the costs that become the burden of service. This is understandable because it will face greater environmental risks if waste is not managed effectively. According to Handoko (1993) effectiveness relates to the ability to choose the right goal or the right equipment to achieve the set goals. The effectiveness of public services is more results-oriented and objectives with a level of satisfaction received. Derajat community satisfaction as a measure of effecttititas does not consider how much cost, energy and time used in providing services but rather focuses on achieving the objectives of public service organizations that are cool. Waste management as a public service is a process of activities that are systematic, thorough, and sustainable to be the basis of footing in the implementation of waste management. The local government is responsible for ensuring the implementation of good waste management and environmental insight with the aim of improving public health and environmental quality and making waste as a resource. Local governments through local technical agencies are authorized to conduct waste management. The process of waste handling activities by the Environment Office of Bitung City as the organizer of waste management is carried out through the process of sorting, collecting, transporting up to the final processing and processing.

\section{Results of each indicator:}

\section{Sorting garbage}

The garbage in temporary shelter has not been sorted, the number of TPS and TPS is separated less and not maintained, Garbage sorting by officers is still limited.

2. Garbage collection

Not all garbage can be collected by street sweepers, not all places / areas there are garbage collectors / sweepers.

\section{Garbage transportation}

Not all garbage can be carried on the lines and areas of transportation both in TPS and outside TPS, not all regions can be reached by garbage transportation fleet, the number of transportation fleets and working time and ritasi are still limited.

4. Waste Processing 
Limited number of waste processing officers, lack of discipline of processing officers to regulate working time, limited facilities and infrastructure supporting waste processing.

The below elaboration describes about the result of the research:

\section{Sorting garbage}

Based on the results of the study there is a volume of waste dumped by the community so many places, both in tps / containers and outside tps, and has not been sorted according to the type of garbage. The number of TPS and TPS facilities is reduced, damaged and poorly maintained so that it can not accommodate all the garbage available. Garbage sorting by officers is still limited. Efforts to sort the waste that should be done by the community (household) has not been done. Public awareness so that the sorting of garbage done from home has not been fully implemented. The amount of garbage sorted from the house by the community is still limited even most of it has not been sorted. With the number and condition of tps sorted that there is not all garbage can be accommodated in the existing TPS. The results of waste sorting are highly dependent on the participation of the community and support the allocation of budgets for the procurement of waste and repair of waste sorting facilities that are still limited. From the results of the study identified three problems of waste sorting, namely: (1) Labor, (2) Garbage Shelters, and (3) Community Participation. Public Administration Science according to Basuki (2018) is the process of cooperation of a group of people based on the values of service, high rationality, effectiveness, and efficiency to the resources owned by the organization to achieve predetermined goals. Public administration should prioritize the process of activities involving humans as the main resource of implementing and interacting in a managed organizational container by utilizing facilities and infrastructure to achieve a predetermined goal. The effectiveness of services in waste management must be done through a process of cooperation to achieve the objectives by preparing and utilizing resources both human resources and facilities and infrastructure to support the entire process and results can be maximized to achieve the expected goals. The availability of human resources is important to be pursued and empowered as needed. Technically limited hygiene personnel will not be able to carry out waste sorting such as dry waste, wet garbage and so on. Labor shortages can be overcome by the increase in labor, the consequences of having to prepare the costs (salaries / wages) of workers. The addition of janitors / workers must be in line with the arrangement of wages and payroll in the Regional budget. Demikin also with facilities and infrastructure including the maintenance for tps garbage plus, which is damaged replaced and requires continuous maintenance and maintenance. The conception of public administration is the basic principle of focusing on excellent public services. Excellent public service in the era of good governance should 
involve the public. Therefore, it is necessary to be aware of the public's responsibility and community participation in sorting waste from sources. All interested governments, masayrakat and businesses must have the same understanding in order to have motivation and awareness of the importance of waste handling. It is necessary to do mentoring and coaching continuously by involving all stakeholders.

\section{Garbage collection}

Garbage collection which is a form of garbage collection and transfer from the source of garbage to temporary garbage shelters (TPS / TPST) has not been well set. This is because the community has not complied with the time and place of disposal of garbage in accordance with the provisions, not all garbage can be collected by road sweepers and not all places there are road collectors / sweepers, Lack of supervisory function of field supervisory officers in supervising sweeping in the work area. The problem of delays in garbage collection to shelters, the main cause of the community to dispose of garbage no longer knows the time and place of flooding almost all the time, so scattered in various places, although it has been socialized and determined about the waste disposal hours at 18.00 wita until 06.00 wita. It takes awareness and discipline, from all parties to comply with the provisions of the time and place of garbage collection. Even with the number of garbage collectors / sweepers prepared is still limited cause not all areas there are sweepers prepared to collect garbage on the road so that there are a number of garbage lying around, has not been collected and cleaned. Collecting officers have not been disciplined in work, often do not enter work without notice, late arrival and quick return home. Field supervisors have not conducted maximum supervision according to the placement area. Direct surveillance efforts followed by coaching meetings in the field every week, have not shown significant results. Related to the above problems, in public service management can be said there are weaknesses in waste management. It should be arranged and arranged in the management of the division of areas according to the burden of duty, the area of service, as well as the location with a large concentration of garbage, must be followed by the placement of officers proportionally. The conception of public service management has reminded that service personnel must be tailored to the needs in the field. In terms of the effectiveness of supervision functions in the ministry according to Gibson in Tangkilisan (2005) conducted with a system of supervision and control that is educational. Given the imperfect human nature with limitations if not supervised the work is not maximal and effective. Supervision and control must be carried out in stages at all times continuously to supervise all activities so that the janitor does not deviate from the specified 
objectives. The results of supervision must be followed up by sanctions and awards so that the results of the work can be maximized.

\section{Garbage transportation}

The most important factor in waste management in Bitung City is the transportation of waste. What does it mean that the garbage that has been collected and separated if it is not finally transported. In fact, there is always garbage left inside the TPS and also outside the TPS that has not been transported or passed, left piled up and far from the TPS and the path of garbage vehicles I motorcycles so that it has not been reached garbage transportation. This is more due to the limited number of transport fleets and transport officers, working time and transportation ritasi. Unreachable transportation of waste in certain areas with limited fleets, technically operational and for the benefit of service, it is necessary to prepare special vehicles with the addition of ritasi and ektra transportation that can be directed at any time. Referring to SNI 19-2454-2002 the transport pattern can be done with a direct individual collection system (door to door) with dump trucks or with container emptying systems with Armroll truck vehicles. With special vehicles in question can minimize the possibility of the presence of garbage that accumulates that have not been handled. With regard to the limited number of transport officers available to do work as garbage workers I garbage carriers can be psychologically understood because not everyone wants and is ready to work for this type of work. According to Steers in Tangkilisan (2005) that one of the factors that affect the effectiveness of work is the characteristics of workers that are strongly related to the difference in the individual role of workers in relation to effectiveness. The views of workers differ on purpose based on different abilities. This causes there to be variations in the nature of workers that cause people's behavior to differ from each other in expressing attachment to the organization and performance of individual work. Specifications on the type of work as a garbage carrier requires the preparedness of a special officer as a backup who is ready to work at any time, with adjustable working time and does not reduce the transportation ritasi in accordance with standard operational procedures. Limited number of fleets should be a serious concern for the addition of the fleet by maximizing its maintenance and maintenance, so that the service life of the facility can be extended. Technically qualified facilities and infrastructure have become a necessity in public services. According to Gibson in the tank (2005) that one measure of the effectiveness of the work of the organization is the availability of work facilities and infrastructure available and prepared by the organization in providing public services so that work capabilities can be maximized to achieve the goal. The support of the facilities and infrastructure needed should be provided in accordance with the capacity of management and needs of the region and the range of services by paying attention 
to aspects of maintenance and maintenance as needed. The readiness of the transportation fleet in terms of the number and capacity in the process of transporting waste has become the main need. But the arrangement of the provisions of working time or transportation ritasi is also important. Technically, this can be maximized by supervision and the mechanism is adjusted to the provisions of operational standards. The importance of transportation of waste as a public service is felt and in direct contact with the needs of the community, if neglected and there is unhandled garbage fertilization and will greatly affect human activities and the surrounding environment. In terms of aesthetics will provide a poor view in the development and progress of the city but also in terms of health has the same impact on public health. Judging from the glasses of public service management has not been effective waste management is more due to poor public services. The concept of public service suggests that good service must meet the requirements as stated in Kepmenpan No. 63/Kep/M.PAN/7/2003 on General Guidelines for Public Service Implementation which includes Simplicity, Clarity, Time Certainty, Accuracy, Security, Responsibility, Completeness of Facilities and Infrastructure, Ease of Access, Discipline, Politeness and Hospitality and Comfort. (Menpan, 2003). That public services are based on provisions, must always be able to answer the needs of the community. Public service is an obligation that must be done and prepared by the service provider. Maximizing the transportation of waste is done to provide excellent service and felt by the community as a need that must be fulfilled.

\section{Waste processing}

The process of waste processing is carried out in the form of changing the characteristic, composition, and amount of waste carried out through waste processing facilities. This waste processing is done in TPS $3 R$, compost house and processing in landfill. This processing process is done by separating inorganic and organic waste both in quantity and composition. In fact, processing through sorting and separation is only done in a limited number causing the next process has not given maximum results according to the capabilities of the processing facility. The ineffectiveness of the waste processing process at this late stage is hit on two main problems: (1) Limited human resources, and not yet disciplined in regulating working time; (2) Facilities and infrastructure that have not fully supported. For human resource problems as the main practice must be considered the amount adjusted to the needs of work based on workload and working time, and need to be arranged the division of tasks clearly. The division of basic tasks and functions is carried out by dividing all types of work and distributing technical implementing officers and job handlers. Supervision of the work is carried out at all times especially with regard to working hours, length of work and rest hours. Regularity and punctuality will form workers for discipline dividing 
time according to the demands of the work and the results of work can be maximized in achieving the target work as well as the expected goals. Support Facilities processing infrastructure and final processing becomes a very necessary thing to be prepared before the work and processing is carried out. According to article 23 paragraph 4 PP 81 Year 2012 that each landfill must be equipped with basic facilities, environmental protection facilities, operating facilities, and supporting facilities. All of them are technical requirements that must be met, including the technical design of land and landfill development with supporting equipment facilities. With the requirements of facilities in accordance with the provisions allow the processing process can run and minimize its impact on people and the environment.

Based on the results of the study, there were several factors that influenced the effectiveness of waste management in the Environment Office of Bitung City: 1.) Human Resources Factors. Human beings become a factor in the management of servants, especially in providing public services. Success in the process of handling waste is largely determined by human factors with all its abilities and commitments. In handling waste requires sufficient personnel and technical capabilities by relying on manpower as the main focus of doing the job with the will owned. The reality with a limited number and most of the workers / janitors are those who have a low level of education with all the limitations of understanding about the demands of the job. This can be seen from inconsistencies in complying with working time, returning home quickly, as well as not all garbage is cleaned and transported. With limited number and commitment and work responsibilities should be interpreted as needs that must be met and prepared. Work can be done effectively if the planned expansion of the service area is proportional to the availability of human resources needed, and equipped with work commitments and responsibilities. 2.) Supporting facilities and infrastructure. One of the important things in the process of handling waste is the availability of facilities and infrastructure in streamline the results of public services. Waste handling is in dire need of support of facilities and infrastructure with the appropriate capacity. Lack of transportation fleet, limited road operation, lack of tps containers sorted and TPS3R facilities, lack of landfill capacity has caused the waste handling flow does not run as it should. The ability of organizations in providing public services is largely determined by the capabilities of existing resources including the availability of facilities and infrastructure. The effectiveness of public services will provide maximum results when service management can be managed according to needs. The necessary facilities and infrastructure should be provided in accordance with the capacity of management and regional needs and the range of services. Support of facilities and infrastructure has become a condition that must be met in providing public services. 3.) Regulatory and regulatory factors. In 
the handling of waste aspects of enforcement of the rules contained in the form of regulation is necessary for the creation of discipline and compliance with existing rules. Regulations that do not run in accordance with the provisions will affect the effectiveness of public services including waste services. This is seen in the provisions of working time has not been met because it arrives late or returns home quickly, the number of transportation ritasi is not met according to the provisions, and does not enter work without notice. In improving the quality of public services, it takes commitment in the implementation of regulations including regulations to achieve the level of achievement of goals.

Consistency in regulatory supervision is required in the effectiveness of achieving organizational objectives. Enforcement of the rules must always be adhered to and can have a positive impact both in the environment of implementing institutions and the general public as objects of service. Enforcement of the rules with reward and punishment is an important thing to do. All of them require a structured policy in service management so that the effectiveness of work can be maximized. 4.) Limited landfill area. With the wideness of landfill land and the use of landfills that have not been in accordance with technical provisions have affected the effectiveness of waste processing in landfill. The utilization of waste from sources and from the community that has not been done has made the life of landfill shorter. The expanded level of service contributes greatly to the volume of waste that goes into landfill. Public services will run well when accompanied by a planning process based on projections / studies on the capabilities and targets of service time. The service time period must be supported by the capability and availability of facilities with a planned target time so that the use of resources can be maximized. Determination of landfill land and capacity should pay attention to the occurrence of waste, service level, and processing activities carried out. Land capacity use should also pay attention to the life of more than 10 years in accordance with the provisions of SNI 03-3241-1994 on the procedure of choosing the landfill site. Thus the need for land capacity is very important to be considered in planning so that the projected target of use and utilization will be maximized in accordance with the needs and lifesaving set.

\section{CONCLUSIONS}

Based on the results of the data analysis, and information concluded that waste management at the Bitung City Environment Office has not been effective, caused by: 1.) Garbage collected in temporary shelters has not been sorted and separated according to the type between organic waste and inorganic waste. 2.) Garbage collection by field officers in all regions has not been maximized. 3.) Limited number of fleets, transportation, and working time and transportation 
ritasi. 4.) Not yet maximum processing and utilization of waste through waste processing facilities. 5.) There are several factors that affect the effectiveness of waste management in the Environment Office of Bitung City, among others; Human resources, Facilities and infrastructure, Regulations and regulations, Limited landfill area.

Therefore, in waste management at the Environment Office of Bitung City is recommended: 1.) Socialize to all Stakeholders continuously about the utilization of waste of economic value through sorting and separation of waste according to type. 2.) Improve the ability of human resources from field officers both in number and quality so that garbage collection can be maximized. 3.) Need to increase the number of fleets, transportation, and working time and transportation ritasi. 4.) Perform processing and utilization of waste to the maximum through waste processing facilities. 5.) To support the effectiveness of waste management in the Environment Office of Bitung City, the human resources need to be added, the addition of the number of facilities and infrastructure and carried out maintenance as needed, regulations and regulations must be enforced, limited landfill area needs to be expanded.

\section{REFERENCES}

Azhar K. (2003). Pelayanan Publik. Universitas Brawijaya

Badan Standardisasi Nasional, SNI 19-2454-2002 Tentang Tata cara Teknik Operasional Pengelolaan Sampah Perkotaan.

Basuki, J. (2018). Administrasi Publik Telaah Teoretis dan Empiris. Depok: PT. Raja Grafindo Persada.

Gibson, James L., dkk.(1994). Organisasi dan Manajemen; Perilaku, Struktur, dan Proses.Jakarta: Erlangga.

Hadiwiyoto, S.(1983). Penanganan dan Pemanfaatan Sampah. Jakarta: Yayasan Idayu Handayaningrat, S .(1985). Pengantar Studi IImu Administrasi dan Manajemen. Jakarta :

Gunung Agung.

Handoko, T. H. (1993). Manajemen. Yogyakarta: Edisi Kedua Cetakan ketujuh. BPFE.

Keputusan Menteri Pendayagunaan Aparatur Negara No. 63/Kep/M.PAN/7/ 2003 tentang Pedoman Umum Penyelenggaraan Pelayanan Publik.

Kobogau, J. Sumampow, I \& Kumayas, N. (2018). Kinerja Dinas Kebersihan Dalam Pengelolaan Sampah Kabupaten Mimika. Jurnal Eksekutif, 1(1)

Kodoatie, Robert J. (2003). Manajemen dan Rekayasa Infrastruktur. Yogyakarta: Pustaka Pelajar. 
Lumiu, A. N. (2017). Efektivitas Pelayanan Kebersihan Perusahaan Daerah Kebersihan Kota Bandung di Kelurahan Pasirkaliki. Bandung. (Doctoral dissertation, UNPAS).

Masengi, E.E. (2018). Pengantar Manajen Pelayanan Publik. Malang: Wineka Media.

Nurhasyim. (2004). Pelayanan Prima. Jakarta: Graha Ilmu

Nurmandi, A (1999). Manajemen Perkotaan. Yogyakarta: Lingkaran Bangsa.

Pasolong, H. (2008). Teori Administrasi Publik. Bandung: Alfabeta.

Peraturan Pemerintah Nomor 81 Tahun 2012 Tentang Pengelolaan Sampah Rumah Tangga dan Sampah Sejenis Sampah Rumah Tangga

Ridwan, J \& Sudrajat A.S. (2019). Hukum Administrasi Negara dan Kebijakan Layanan Publik. Bandung: Penerbit Nuansa Cendekia.

Saputra, M. R., Winarni, L., \& Bhudianto, W. (2017). Efektivitas Kerja Pegawai Pada Dinas Pendidikan Kabupaten Sukoharjo. Transformasi. 2(29).

Sedarmayanti. (2009) Reformasi Administrasi Publik, Reformasi Birokrasi, dan Kepemimpinan Masa Depan. Bandung: PT Refika Aditama.

Siagian S. P. (2017). Filsafat Administrasi. Jakarta: Bumi Aksara.

Sinambela, L. Poltak. (2006). Reformasi Birokrasi. Jakarta: Bumi Aksara .

Sugiyono. (2018). Metode Penelitian Kuantitatif. Bandung: Alfabeta.

Sutopo \& Suryanto, A.( 2003). Pelayanan Prima. Jakarta: Lembaga Administrasi Negara Republik Indonesia

Tangkilisan, Hessel, Nogi, S. (2005). Manajemen Publik. Jakarta. Gramedia Widiasarana .

Torang, S. (2016). Organisasi dan manajemen.(Prilaku,struktur,Budaya \& Perubahan Organisasi) Bandung: Alfabeta.

Undang Undang Nomor 18 Tahun 2008 Tentang Pengelolaan Sampah Undang Undang Nomor 25 Tahun 2009 Tentang Pelayanan Publik 